\title{
Tectonic and Hydrothermal Activities in Debagh, Guelma Basin (Algeria)
}

\section{Said Maouche, ${ }^{1}$ Abdeslam Abtout, ${ }^{1}$ Nacer-Eddine Merabet, ${ }^{1}$ Tahar Aifa, ${ }^{2}$ Atmane Lamali, Boualem Bouyahiaoui, ${ }^{1}$ Sofiane Bougchiche, ${ }^{1}$ and Mohamed Ayache ${ }^{1}$}

\author{
${ }^{1}$ CRAAG, BP 63, Bouzareah, 16340 Alger, Algeria \\ ${ }^{2}$ Geosciences-Rennes, CNRS UMR 6118, Université de Rennes 1, Bat.15, Campus de Beaulieu, 35042 Rennes Cedex, France
}

Correspondence should be addressed to Said Maouche; said_maouche@yahoo.fr

Received 26 September 2012; Revised 9 January 2013; Accepted 21 January 2013

Academic Editor: Salvatore Gambino

Copyright (C) 2013 Said Maouche et al. This is an open access article distributed under the Creative Commons Attribution License, which permits unrestricted use, distribution, and reproduction in any medium, provided the original work is properly cited.

\begin{abstract}
Quaternary and Pliocene travertines, deposited from hot springs, can reveal much about neotectonic and hydrothermal activity. The aim of this work is the understanding of the actual tectonic activity in the Guelma Basin and in one of its spa structures. Gravity data were collected during a field study in the Hammam Debagh (HD) area and then analyzed to better highlight the architecture of its subsurface underlying structures. This analysis was performed by means of a Bouguer anomaly, upward continuations, and residual and derivative maps. Comparison of gravity maps, field geology, geomorphic observations, and structural maps allowed us to identify the major structural features in the Hammam Debagh. As a result, we confirm the position of the Hammam Debagh active fault which is superimposed to the hydrothermal active source in the NW-SE direction characterized by a negative gravity anomaly.
\end{abstract}

\section{Introduction}

Plio-Quaternary travertine deposits from hot springs can reveal much about the neotectonic history as demonstrated by many examples worldwide [1]. Several open cracks parallel to active normal faults were identified in deposits at Pamukkale, Turkey [2]. In New Guinea, travertine deposits are controlled by fracturing [3]. Numerous studies show how the deposition of travertine has ceased in relation to tectonic activity (i.e, Hula Valley, Israel [4]). Other examples of tectonic activity on a normal fault generating hydrothermal systems are known at Mammoth Hot Springs [5] in Slovakia [6]; Aveyron, France [7], and Shelsley, United Kingdom [8].

Tilting, warping, and faulting of the Algerian crust were followed by travertine formation [9]. Several hydrothermal systems and associated travertine deposits are identified in the Tellian Atlas (e.g., Hammam Debagh (HD) in the eastern part and Hammam Boughrara in the western part).

Along the Tellian Atlas (Figure 1), most of the hydrothermal sources are located along active faults, activated or reactivated during major seismic events such as Bouchegouf and Hammam N'bailis faults [10, 11]. Hammam Debagh (HD) hydrothermal source is located in the western part of the Guelma Basin and is one of the famous spas in northeastern Algeria $[10,12,13]$. The HD area is situated in the western limit of the Guelma Plio-Quaternary pull-apart basin created between two overlapping east-west dextral strike slip faults $[10,14]$. This active hydrothermal source is responsible for several meters' thickness of travertine deposits. The presence of active hydrothermal source indicates the presence of fault not observed so far. This tectonic feature represents an important element to be clarified since it also represents the structural emplacement of the western limit of the Guelma Neogene basin (Figure 2). This area experienced several seismic events $[11,15,16]$. The seismic activity seems to be related to an NW-SE unknown active fault as shown by focal mechanisms particularly that of $2003 \mathrm{HD}$ earthquake $[15,17,18]$.

In this study, an attempt is made for understanding the recent tectonic activity that generates the seismicity in the vicinity of HD. For that purpose, we used a multidisciplinary 


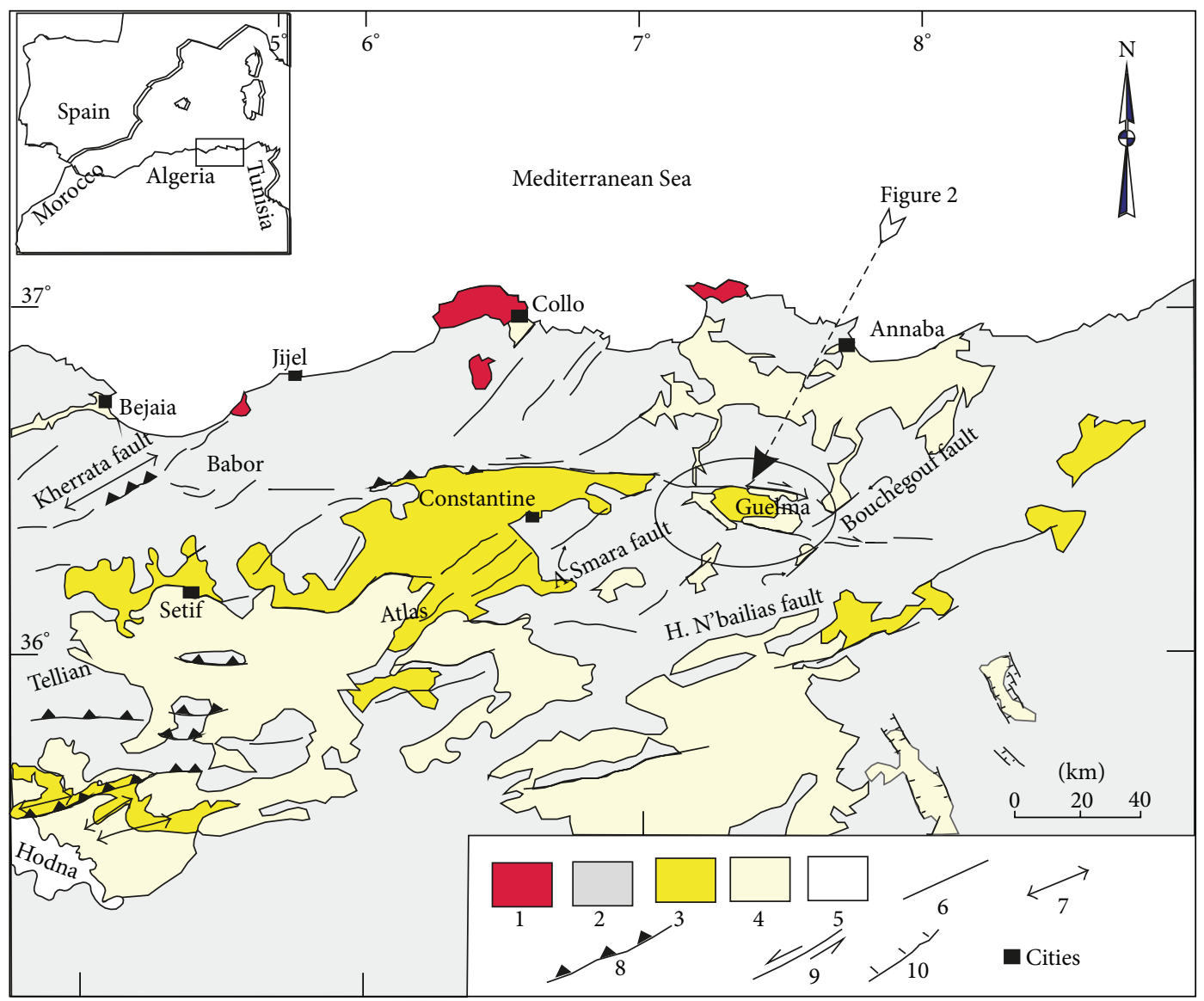

Figure 1: Tectonic map of the Eastern Tellian Atlas of Algeria [11] and the Guelma seismogenic localization: (1) volcanism, (2) JurassicCretaceous and lower Cenozoic basement, (3) Neogene post-nappe deposits, (4) Plio-Quaternary deposits, (5) Quaternary deposits, (6) fault, (7) anticline, (8) reverse fault, (9) strike-slip fault, and (10) normal fault.

approach consisting in the combination of geology (tectonics and neotectonics), geomorphology, and geophysics (gravimetry) with the objective of recognizing and detecting the seismogenic source likely responsible for the hydrothermal activity in the HD-Roknia lineament. The main important result we obtained consists of the localization of the Plio-Quaternary hydrothermal primary source along the structural western limit of the Guelma seismogenic basin.

\section{Geological and Morphological Outline}

2.1. Geological Outline. The Tellian Atlas of Algeria underwent significant tectonics during the Neogene time. Neotectonic features correspond to E-W to NE-SW trending folds, reverse faults affecting Quaternary deposits ([17, 19] and references therein). Along the folded mountains, intermountain Neogene post-nappe Basins are characterized by the presence of Miocene and Plio-quaternary sediments (e.g., Soummam, Hodna, Constantine, and Guelma basins [11, 17]). It is worthwhile noting that the Guelma basin (considered in this study) is rather particular since, as a pull-apart basin, it is not very common in Algeria. This seismogenic basin is situated at the eastern end of the Constantine E-W trending dextral strike slip (Figure 1). This typically pullapart basin formed during the post-nappe period is filled by late tertiary to quaternary sediments. The Mio-Pliocene "post-nappe" continental deposits consist of two sets: (a) sandstone interbedded with marl representing the postTortonian period [10]; (b) at the top, particularly in the HD area, we may find clays and conglomerates, red tuffs, and lacustrine limestone succession. According to Glacon and Rouvier 1972 [20], this series is equivalent to the Messinian observed in Tunisia. The alluvial terraces deposited by Bou Hamdane and Seybous rivers constitute the quaternary cycle of the Guelma seismogenic basin.

2.2. The Hammam Debagh Hydrothermal Source. The HD group of springs is one of the bathing places still in use since the Roman's era. Several studies $[21,22]$ point out their main chemical water composition (Table 1). The output temperature ranges from $88.5^{\circ} \mathrm{C}$ to $97.8^{\circ} \mathrm{C}$. The geothermometric study indicates that the maximum temperature is around $300^{\circ} \mathrm{C}$ at depth. The boreholes drilled in the region evidenced significant abnormalities which range as follows: $1^{\circ} \mathrm{C}-16 \mathrm{~m}$, $1^{\circ} \mathrm{C}-11 \mathrm{~m}$, and even $1^{\circ} \mathrm{C}-7 \mathrm{~m}$ [12]. 

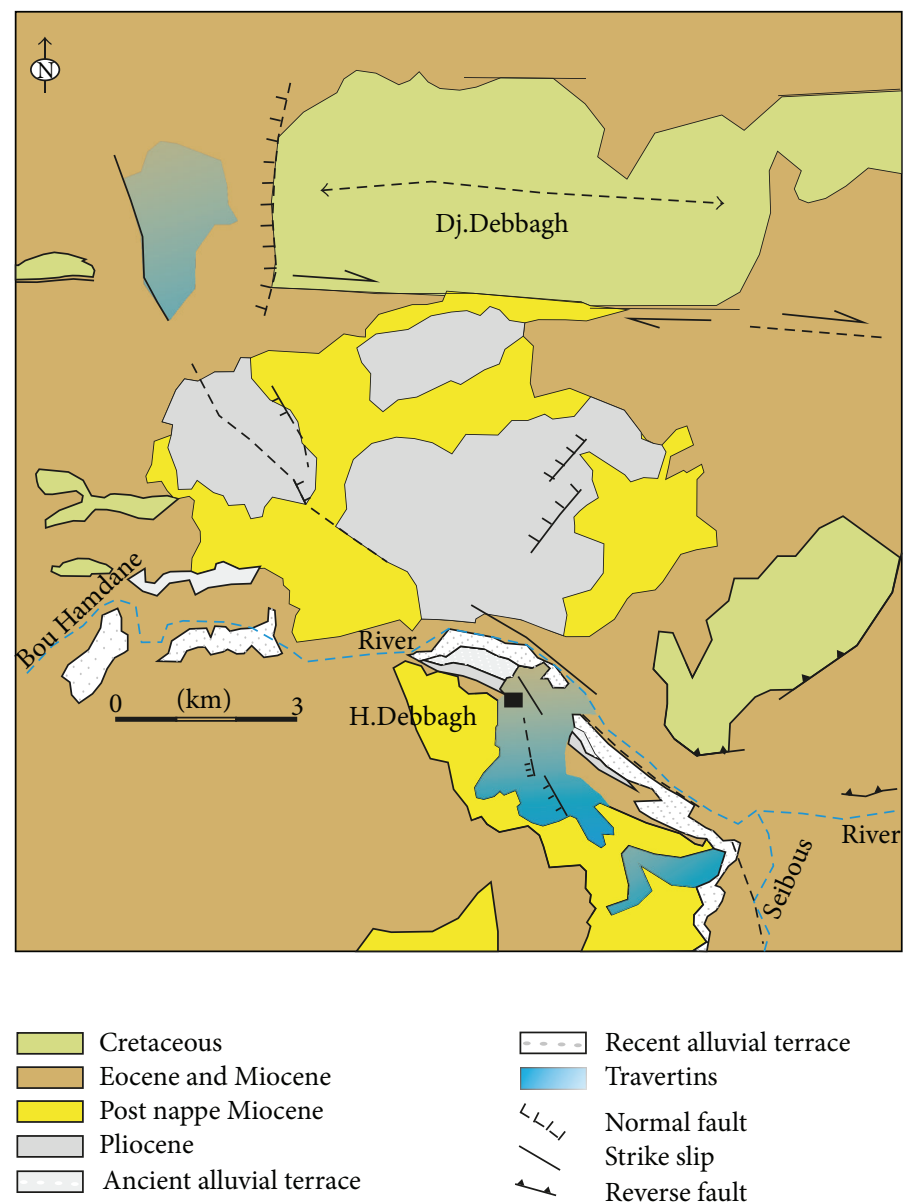

$\begin{array}{ll}\ldots & \text { Recent alluvial terrace } \\ & \text { Travertins } \\ & \text { Normal fault } \\ & \text { Strike slip } \\ \text { Reverse fault }\end{array}$

FIGURE 2: Geological map of the western part of the Guelma basin (see position in Figure 1), showing the study area; full line: observed normal fault; dashed line: interpreted normal fault.

TABLE 1: The Hammam Debbagh thermal springs, principal chemical constituents and physical parameters [13-25].

\begin{tabular}{|c|c|c|c|c|c|c|}
\hline Site & $\begin{array}{c}\text { Temperature of } \\
\text { water }\left({ }^{\circ} \mathrm{C}\right)\end{array}$ & Flow (L/mn) & $\begin{array}{l}\text { Total dissolve } \\
\text { solids (ppm) }\end{array}$ & $\begin{array}{c}\text { Principal chemical } \\
\text { constituents }\end{array}$ & Associated rocks & Remarks \\
\hline $\begin{array}{l}\text { Hammam } \\
\text { Debbagh }\end{array}$ & $88.5-98$ & 6000 & 1.466 & $\begin{array}{l}\mathrm{MgCO}_{3}=257, \\
\mathrm{MgSO}_{4}=176, \\
\mathrm{MgCl}_{2}=416, \\
\mathrm{NaCl}=416, \\
\mathrm{KCl}=79, \mathrm{Gaz}=97 \%, \\
\mathrm{CO}_{2}=2.5 \%, \\
\mathrm{Na}=0.5 \%, \mathrm{H}_{2} \mathrm{~S}\end{array}$ & $\begin{array}{l}\text { Faulted Miocene, } \\
\text { Pliocene and } \\
\text { Quaternary }\end{array}$ & $\begin{array}{l}\text { (i) Large deposits of } \\
\text { travertines containing } \\
\text { Pisolite of Aragonite } \\
\text { (ii) Cloud streams } \\
\text { (iii) Roman careers } \\
\text { (iv) Traces arsenic } \\
\text { (As) } 6.5 \text { ppm }\end{array}$ \\
\hline
\end{tabular}

In addition to the temperature parameter, this water is rich in sodium chloride and calcium sulfate. It contains radon (0.1 and 10 millimicrocuries/L) and arsenic $(0.5 \mathrm{mg} / \mathrm{L})$ and emits hydrogen sulphide [23]. These chemical parameters show that this source can be linked to a magmatic system.

\subsection{The Travertine Deposits and Morphological Structures.} Travertine deposits are calcareous, limestone accumulations formed in lakes, rivers, springs, and caves. They consist of crystalline deposits or incrustations formed by rapid precipitation of calcium carbonate from cold or thermal waters at surface; they show very restricted lateral extent. Travertines of the study area are thermal or hydrothermal calcareous deposits related to HD source, represented by two main facies: the porous biodetrical facies and a constructed one, or the waterfall deposits related to plentiful and regular drainages of waters loaded with calcium, magnesium bicarbonates, and sulphides (Table 1, Figure 3(e)). These deposits, are of laminar type and were deposited in sheets during Pliocene-Quaternary. Southward the village, these facies are mined in active quarries. Locally, the travertine presents 


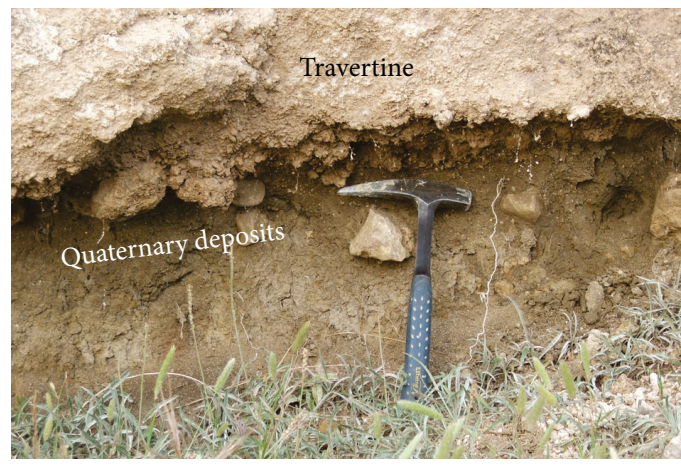

(a)

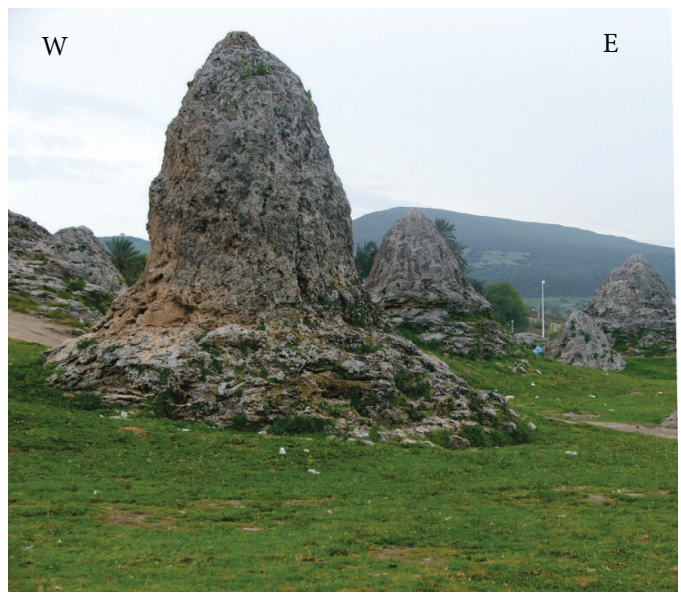

(c)

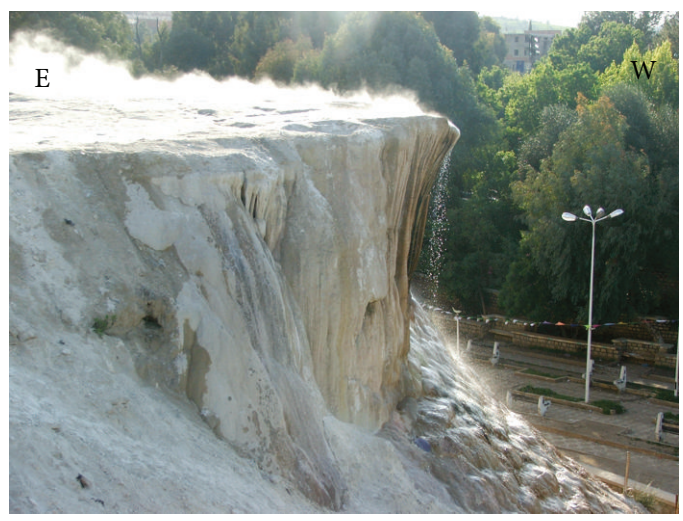

(e)

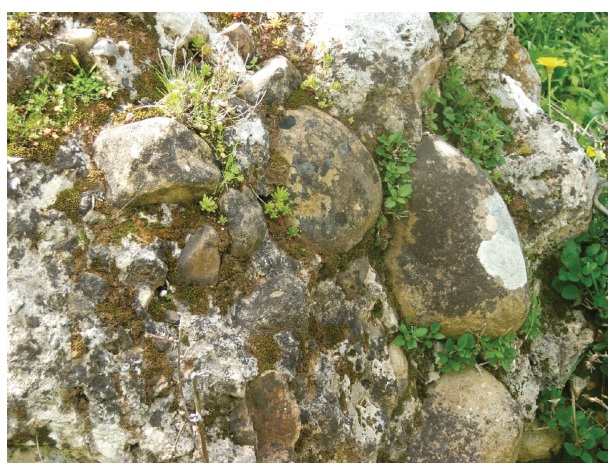

(b)

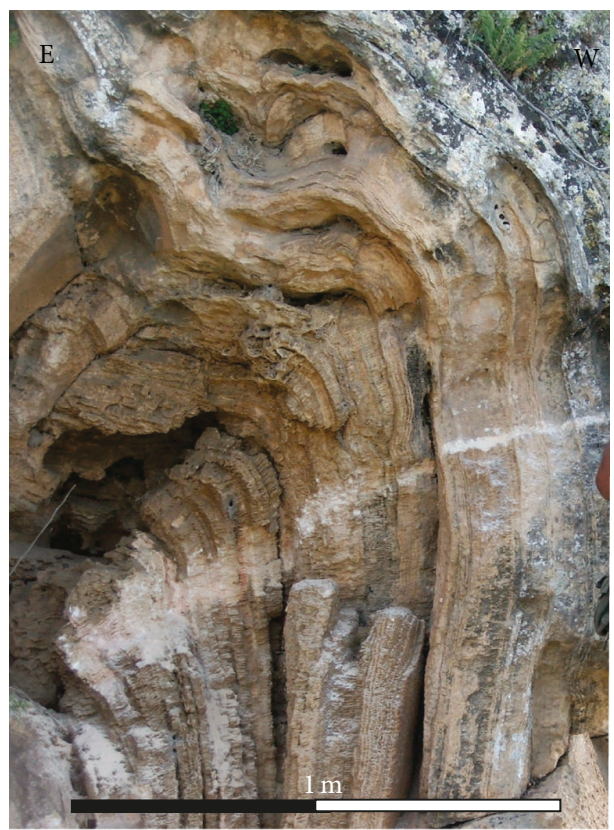

(d)

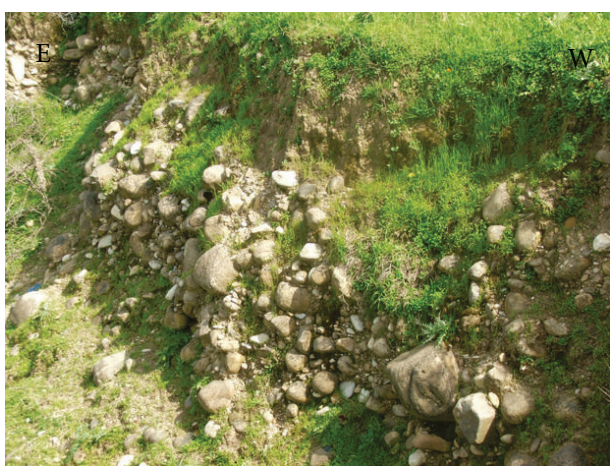

(f)

FIGURE 3: Photographs of the main active site of Hammam Debagh hot springs (HD): (a) travertine accumulation on Quaternary soil; (b) clogged (filling or sealing) alluvial deposits (ancient elevated alluvial terrace); (c) well-developed cone-shaped accumulation, approximately $7 \mathrm{~m}$ high. Note the near vertically dipping layers and the stair-step topography that characterizes terraced mound accumulations; (d) steeply dipping to near-vertical laminae, transverse section through a fissure ridge accumulation displaying the internal structure along the fissure and the downward flow over both sides; (e) present travertine deposition (active thermal spring); (f) the more recent alluvial terrace close to Bou Hamdane river. 


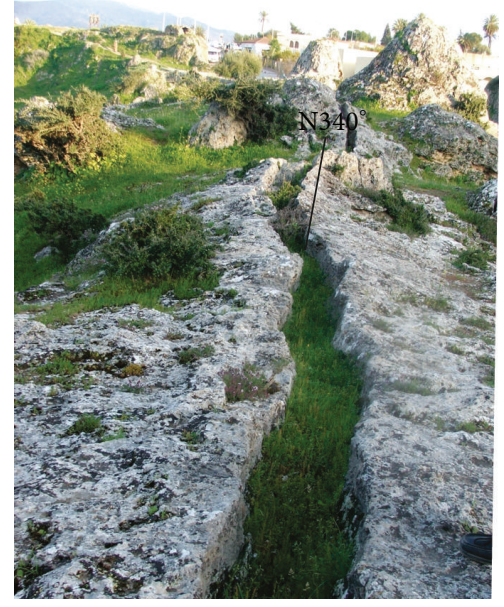

(a)

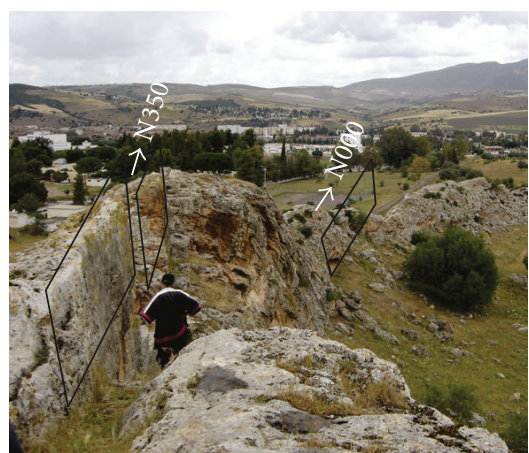

(c)

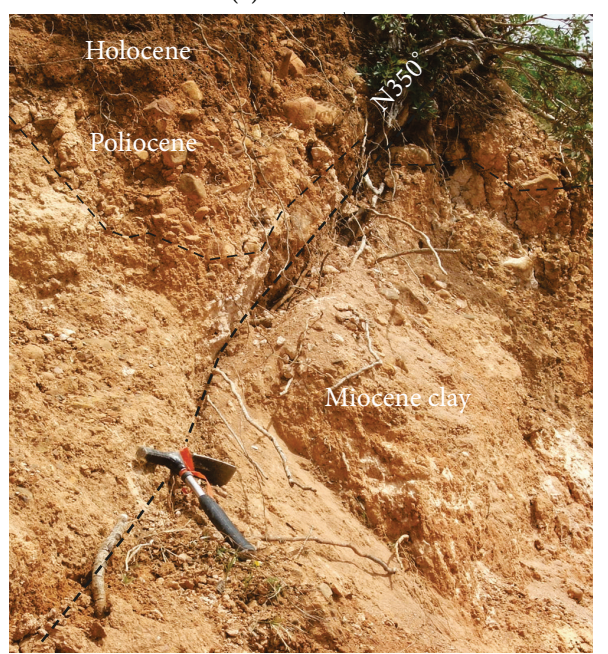

(e)

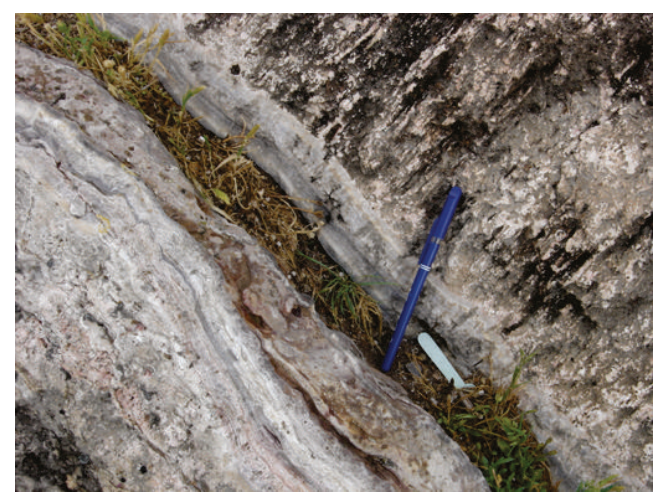

(b)

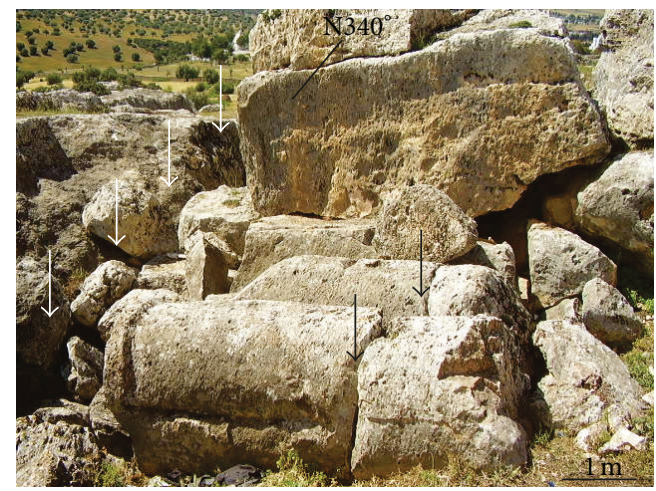

(d)

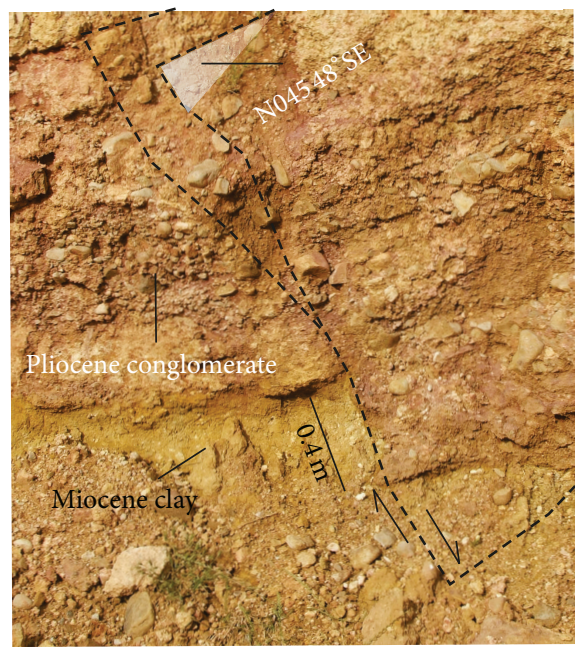

(f)

FIgURE 4: Examples of observed recent tectonic evidences: $(a, b)$ fissured ridge at HD. Travertine precipitates from hot waters that emerge along the axial ridge making up the cone. They are part of a radically different internal structure than the terraced mound deposits; (c) vertical transverse fracture; (d) picture showing surface rupture and broken columns in roman career probably related to an earthquake occurrence; the arrow indicates the position of fracture; $(e, f)$ recent normal faults affecting the Pliocene deposits.

a remarkable feature consisting in low porosity laminates alternating with compact levels. These layers are observed in the coal face of the Roman quarries.

The travertine deposits systematically show conglomerates on their bottom, attesting the presence of a series of alluvial terraces clogged by hydrothermal deposits (Figure 3(b)).
In several cases, they show a quaternary soil on their bottom (Figure 3(a)) that confirms the young age of the HD travertine. Their average thickness is from 10 to $20 \mathrm{~m}$, and they present a little dip. The hydrographic network individualizes at least three levels of alluvial terraces; one of them is represented in Figure 3(f). The dip value variations observed 


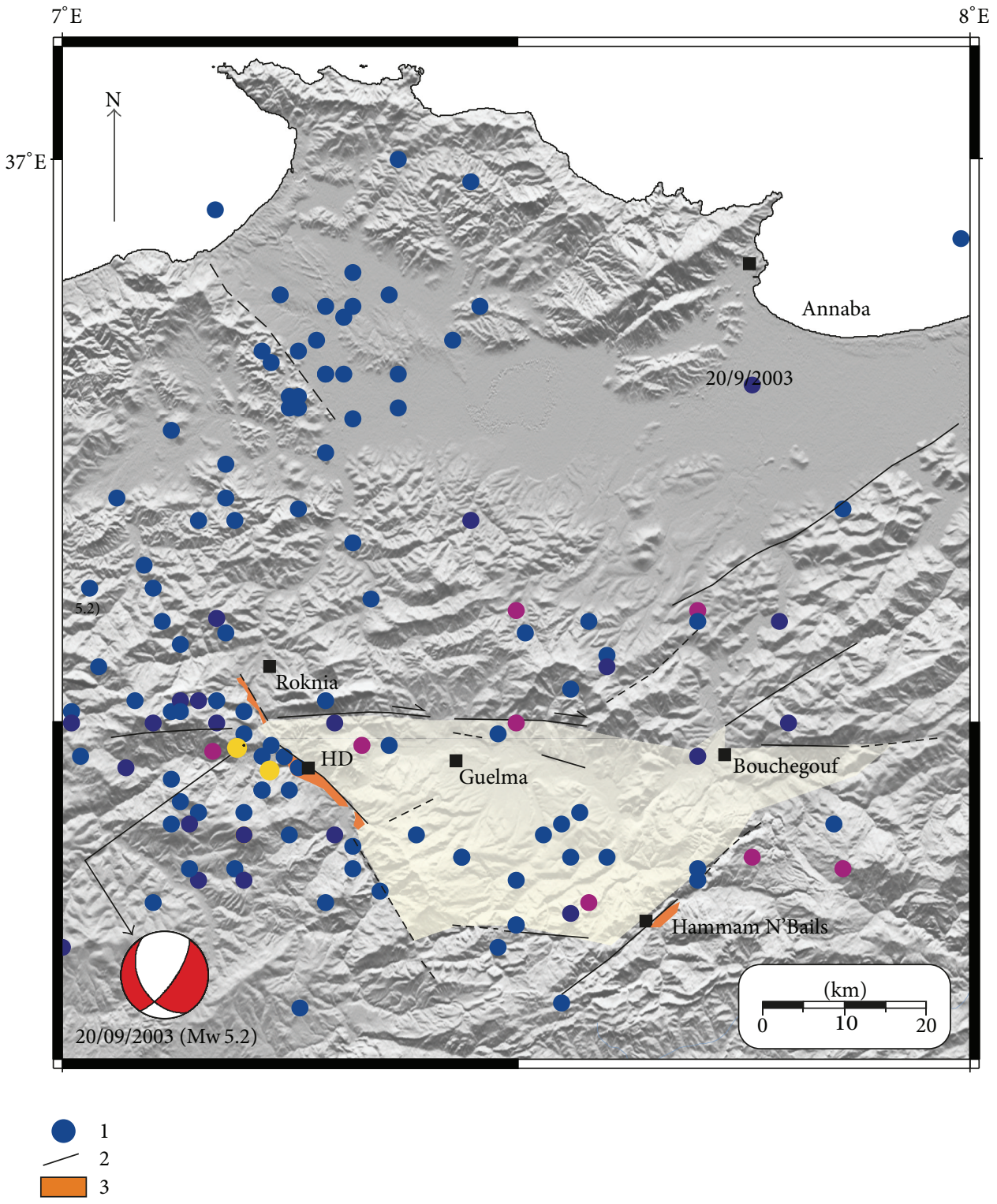

FIGURE 5: Seismicity distribution in the Guelma basin and surroundings: (1) earthquakes, (2) active and potentially active fault, and (3) travertine deposits; yellow circle corresponds to the largest earthquakes that occurred in the region with the focal mechanism of the 20/09/2003 HD earthquake: seismicity data are from [16].

from a terrace level to another one indicate that the lower terrace, close to the Bou Hamdane River, is more recent. The abundance of these alluvial deposits (mainly composed of conglomerates) evidences the existence of strong streaming of the Bou Hamdane River during the Quaternary before it changes its river path, probably in response to tectonic uplift and travertine deposits. In this area, different shapes of positive morphological travertine structures described as dykes, domes, and terraces (Figures 3(c), 3(d), and 3(e)) are injected in the system of alluvial terraces. A regular cone presents a simple cross section with a central orifice and the "parasitic cone" developed after the original cone has become inactive. In the south of the HD, a second facies of travertine outcrops forming a series of small flaps or tatters.
As known, travertine buildups around spring orifices along fractures such as joints of faults form elongate ridges. At this site, one of the ridges' wall exceeds $7 \mathrm{~m}$ height and is elongated in the $\mathrm{N} 340^{\circ}$ direction (NW-SE) (Figures 4(a) and $4(\mathrm{c})$ ). In some cases, we observe precipitations from hot waters emerging along the axial ridge (Figure 4(b)). At the site of the Roman quarry, located south of the village, we observe a significant normal movement on the NW-SE fault (Figure 4(d)). This recent tectonic movement is also observed outside the travertine area (Figures $4(\mathrm{e})$ and $4(\mathrm{f})$ ) and shows normal faults affecting the Pliocene deposits.

2.4. Neotectonics and Seismotectonics. The Tellian Atlas structure is a fold and thrust fault system [17]. Along this domain 


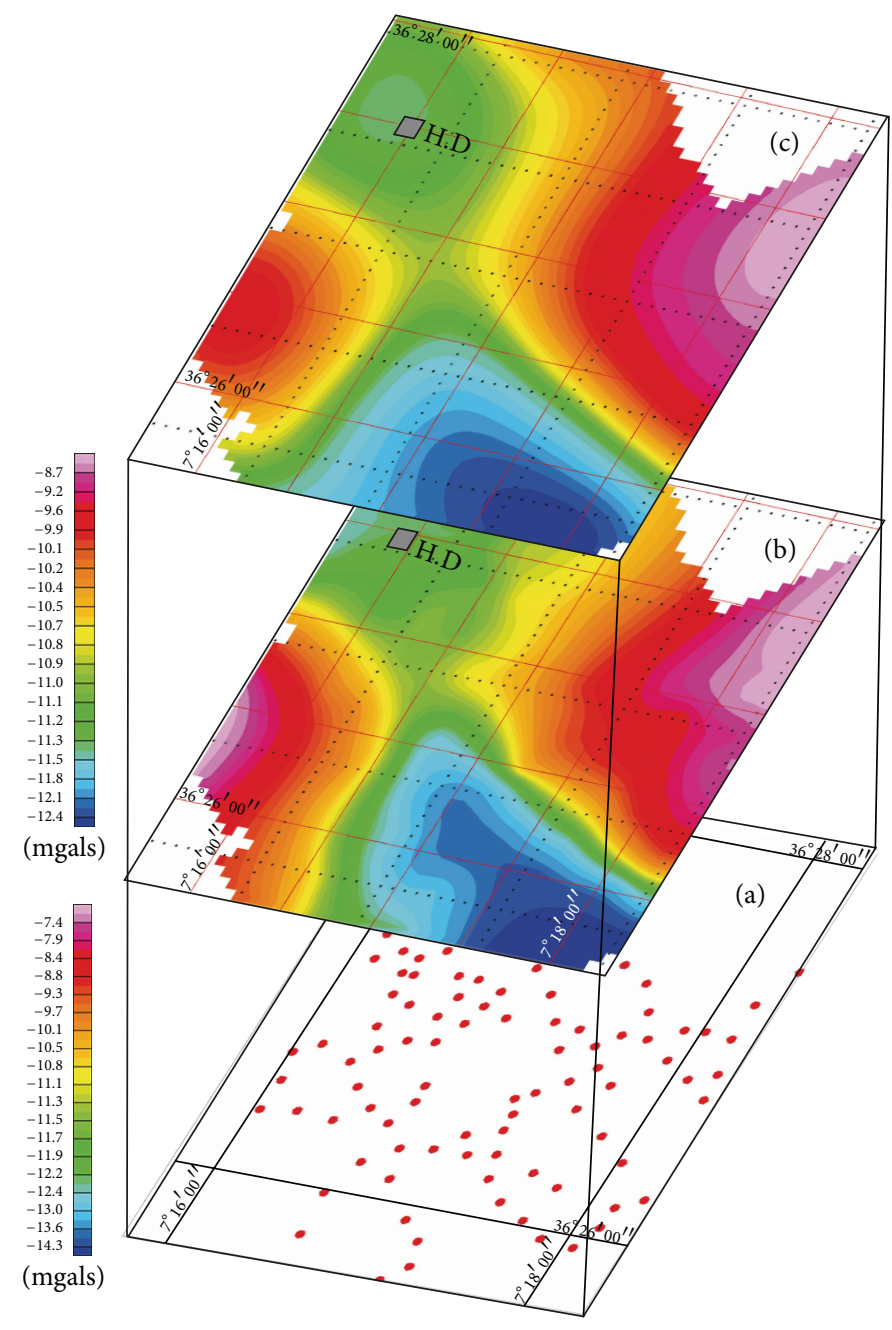

FIGURE 6: Gravity map: (a) gravity station survey, (b) Bouguer anomaly map, and (c) $500 \mathrm{~m}$ upward continuation.

(Figure 1), the recent tectonic activity responsible for the moderate seismicity is related to the $5-6 \mathrm{~mm} / \mathrm{y}$ convergent movement of the African plate towards the Eurasian plate, with an NNW direction [24-26]. The stress field acting along northern Algeria generates tectonic structures in the NESW and E-W direction. According to several studies [14, 17, $19,22]$, the structures of the postthrusting intermountain Neogene basins are characterized by reverse faulting in the western and central part of the Tellian Atlas domain, as attested by the rupture mechanism highlighted by the focal mechanism of significant earthquakes, whereas strike slip mechanism is predominant in the eastern part $[11,16,17]$. In the Guelma seismogenic basin, earthquakes exhibit focal mechanisms showing normal faulting regime. The size of the pull-apart basin is quite important, and this is linked to the amount of slip and distance between overlapping segments. In this basin (Figure 5), two particular faults are observed. The Bouchegouf and Hammam N'Bailis faults, along which crop out the Quaternary deposits related to hydrothermal springs $[10,11]$, are potentially active and could be in relation to the damaging earthquakes of the Guelma seismogenic zone
(Figure 5) [16, 27]. Several earthquakes struck this region: Héliopolis on December 17, 1850 ( $I_{0}=$ VI EMS); Guelma on February 10, $1937\left(I_{0}=\right.$ VIII EMS, $\left.\mathrm{mb}=5.4\right)$; and recently HD on September 20, $2003(\mathrm{mb}=5.2)$ with a normal fault mechanism (a small strike slip component can also be observed on the focal mechanism of the $2003 \mathrm{HD}$ earthquake in Figure 5).

According to several authors $[10,12,18]$ the HD-Roknia source alignment has neotectonic signification and is related to an NW-SE fault. The field work we carried out reveals fault structures in the same direction, with normal apparent movement (Figures 2 and 5). Such observations are visible in the recent HD travertine deposits. Moreover, juxtaposed alluvial terraces, present in this zone, attest on the vertical movement related to the recent activity on NW-SE to NNW-SSE fault. We notice and confirm a good correlation between the fault-plane orientation observed in the field (cracks in the travertine), from the 2003 focal mechanism and the trends of the geomorphic structures related to the hydrothermal sources (i.e., dykes, ramparts, and cones). The NW-SE to NNW-SSE normal faults are also in agreement 


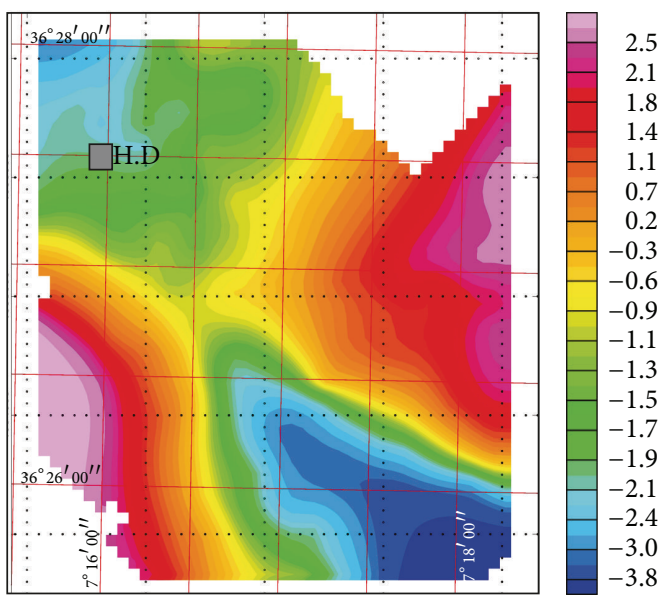

(a)
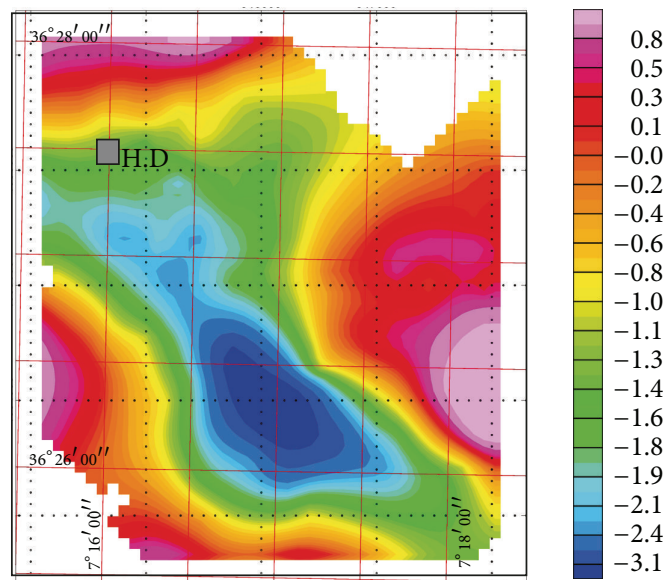

(b)
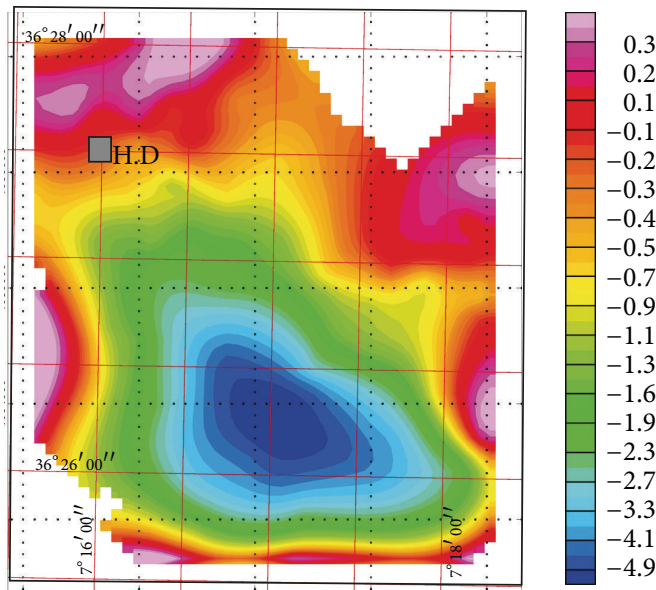

(c)

FIGURE 7: Residual anomaly maps: (a) order 1, (b) order 2, and (c) order 3 .

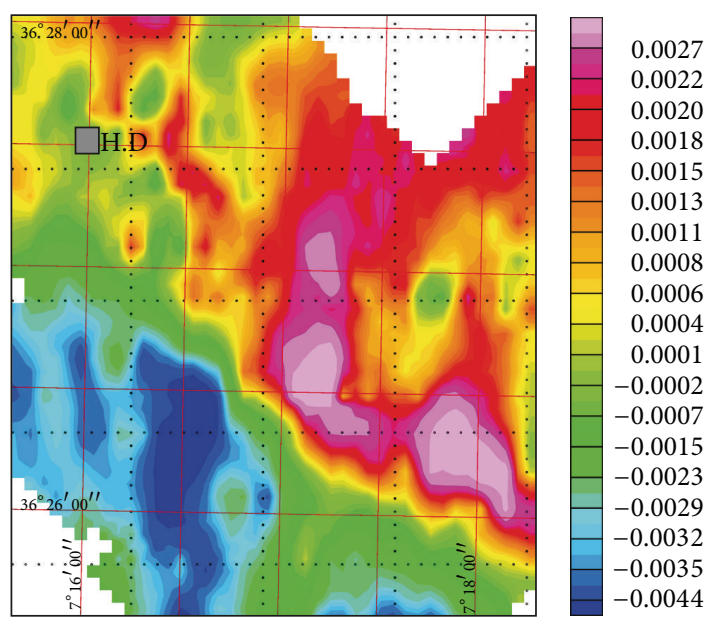

(a)

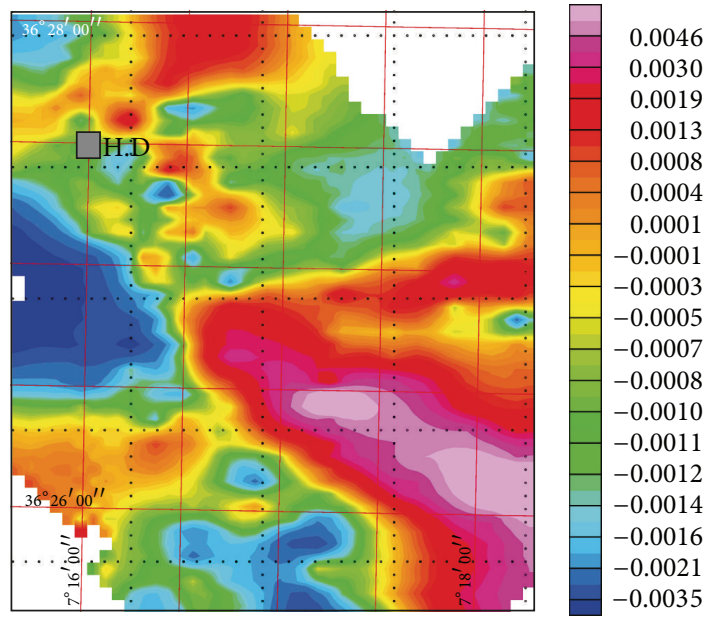

(b)

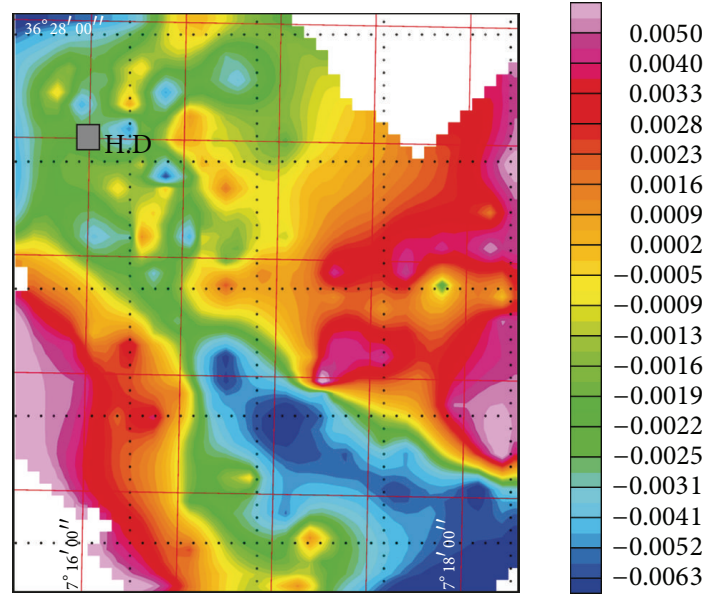

(c)

FIgUre 8: First derivative maps along the three axes $(X, Y, Z)($ drvx, $d r v y$ and $d r v z$, resp.). 


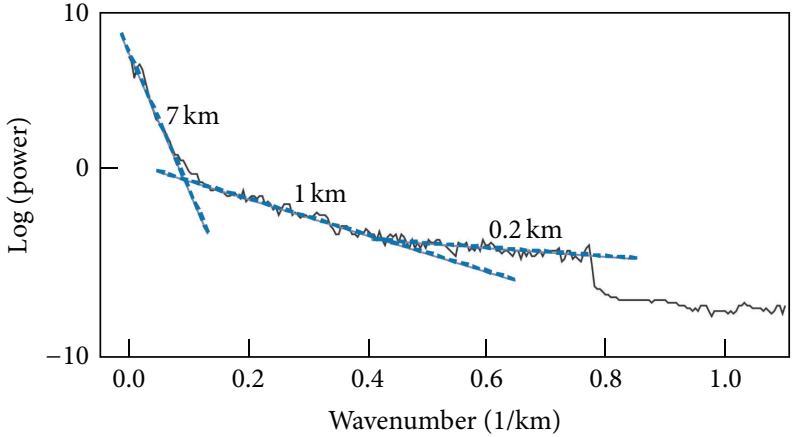

(a)

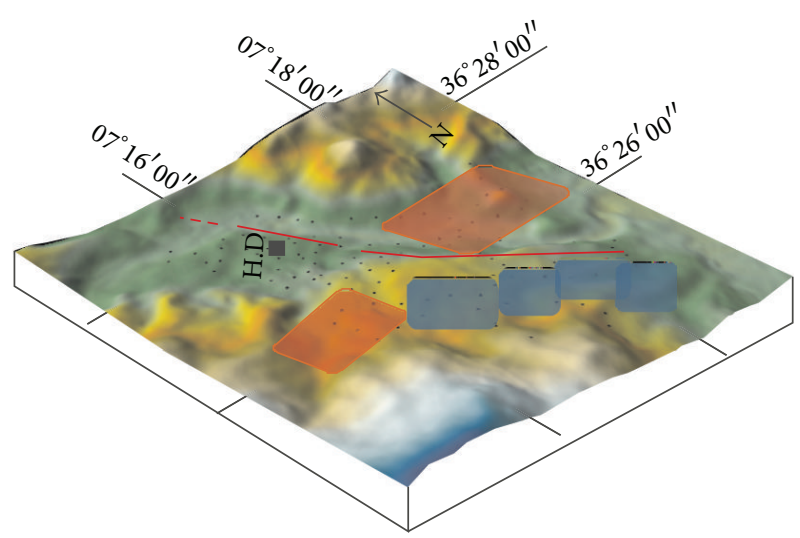

Negative

Positive

Fault position

(b)

FiguRE 9: (a) Radially averaged power spectrum of the Bouguer anomaly showing 3 sources at $0.2 \mathrm{~km}, 1 \mathrm{~km}$, and $7 \mathrm{~km}$ depths; (b) location of the main fault (red line) with the position of the main source depths deduced from the power spectrum.

with the field stress related to the Eurasia-Africa convergence movement.

\section{Geophysical Data}

For a better understanding of the subsurface geology and the tectonic lineament associated with the major HD fault zone, we carried out geophysical investigations.

3.1. Gravity Data. A geophysical prospection was carried out in the vicinity of $\mathrm{HD}$, where essentially travertine deposits crop out. The gravity field values have been measured using the Scintrex CG3 gravity meter. In order to reduce topographic uncertainties, the CG3 has been connected to a differential bifrequency HTECH Z12 GPS with an accuracy of about $10 \mathrm{~cm}$ to better estimate the levelling of the gravity stations. Over 150 stations were collected during this survey (Figure 6) with $0.015 \mathrm{mGal}$ accuracy.

The Bouguer Anomaly. Bouguer anomaly is computed using

$$
A_{B}=g_{m}-\left(g_{\mathrm{th}}-C_{a l}+C_{p}-C_{T}\right),
$$

where $g_{m}$ is the measured gravity at a given station, $g_{\text {th }}$ represents the normal theoretical gravity calculated within the IUGG1967 system, and $C_{a l}, C_{p}$, and $C_{T}$ are the free-air, plateau, and topographic corrections, respectively.

$C_{a l}$ and $C_{p}$ are computed taking into account the determined GPS altitudes and with a correcting density value of $2.4 \mathrm{~g} / \mathrm{cm}^{3}$ obtained from the measurements of representative specimen of the geological formations [28].

The Bouguer anomaly map (Figure 6) is drawn from a regular grid of the Bouguer anomaly values obtained by interpolation using the minimum curvature. This map, with amplitudes ranging between -7 and $-16 \mathrm{mGal}$, mainly shows a significant negative anomaly located southeastwards, bordered by two positive anomalies northwards. It includes all the vertical effects from surface to deep sources. To determine the shallow density distribution, we eliminated the "regional" effect by using the polynomial method at different orders. The first residual anomaly obtained by subtracting a polynomial of "order 1" mainly shows the same anomaly as the Bouguer anomaly. The negative anomaly shows an amplitude value of $5 \mathrm{mGal}$ while both positive anomalies reach a value of $3 \mathrm{mGal}$ (Figure 7).

The second residual anomaly map obtained by subtracting a polynomial of "order 2," which represents shallow anomalies, shows a similar distribution as that of a polynomial of "order 1." We also computed a residual anomaly map using a polynomial of "order 3" which shows a negative anomaly as well. This anomaly is located all over the southern part of the map. In order to identify the possible origins of the anomalies and to evidence the possible limits in between bodies, we computed the first derivative maps in three directions ( $X, Y$, and $Z$, resp., Figure 8$)$. On the southern centre of these maps, we may observe a gravity discontinuity-oriented NW-SE. Upward continuation maps at different altitudes filtered the high frequencies and thus highlighted the long wavelength anomalies. For increasing values of upward continuations at altitudes from 0 to $500 \mathrm{~m}$, the main negative anomaly moves to the southeastern part of the map (Figure 6). The anomaly depths, as a function of their wavelengths, are obtained by using the calculation of the Bouguer anomaly average radial spectrum. Three main solutions have been evidenced (Figure 9). The deeper one is located at more than $7 \mathrm{~km}$, while two other particular bodies, shallower, are located at $\sim 1 \mathrm{~km}$ and $\sim 0.2 \mathrm{~km}$. The deeper body 


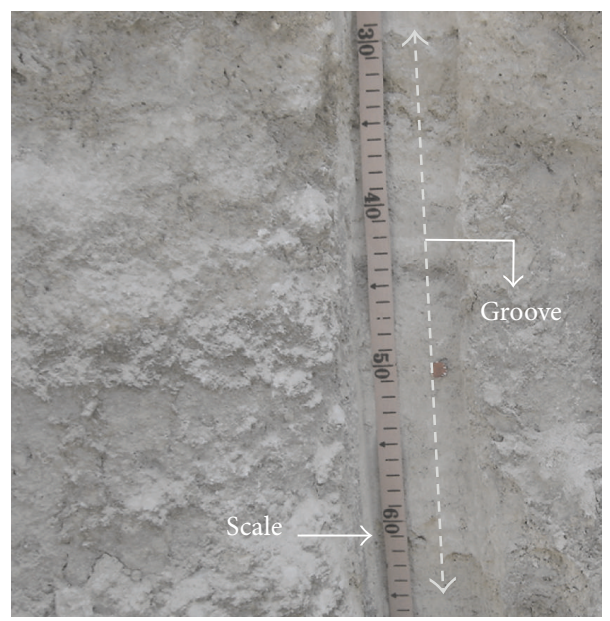

(a)
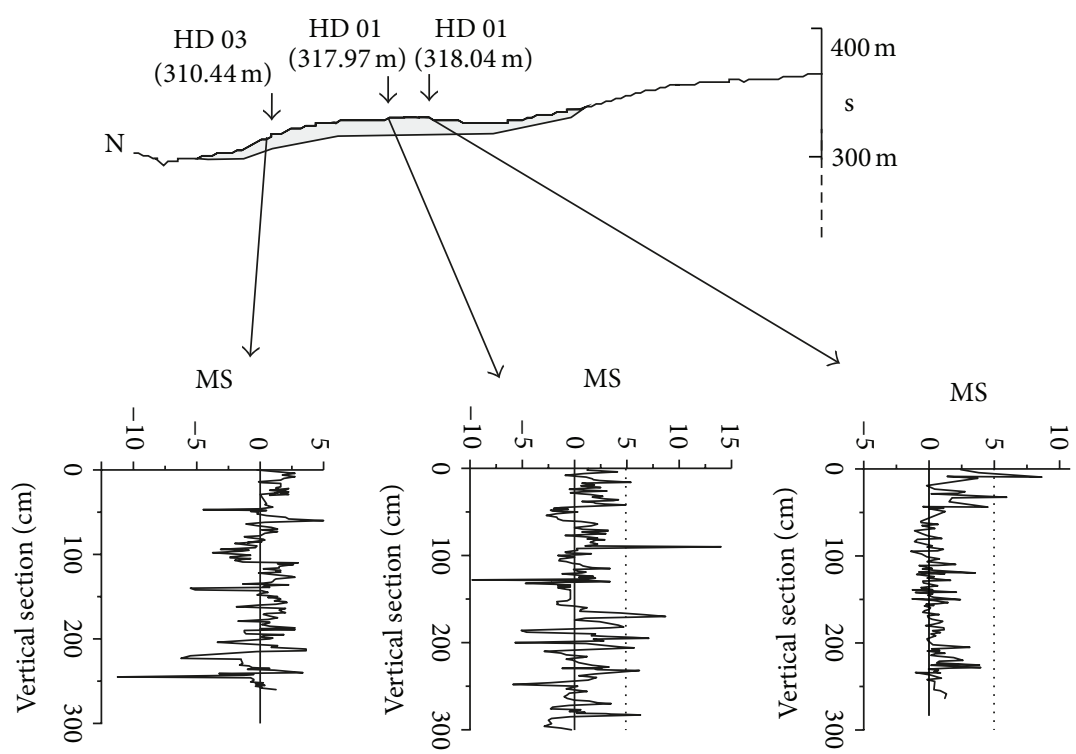

(b)

FIGURE 10: (a) Magnetic susceptibility (MS) measurement along a groove opened for acquisition; (b) MS profiles along N-S topographic cross section on the travertine deposits.

should be a regional structure related to the basement of the Guelma Neogene Basin.

3.2. Travertine Magnetic Susceptibility Measurements. The preliminary rockmagnetic data show that the magnetic signature associated with travertine is generally characterized by low susceptibility values due to the carbonate nature. In order to better understand the process of incrustation, mineralogical enrichment, and paleocurrent flow, magnetic susceptibility signature is used. Magnetic susceptibility (MS) profiles were carried out in several sites. To reduce the local alteration effect, grooves were opened before getting accurate measurement using MS2 sensors. The location and the altitude of the different profiles we measured are calculated using the same differential bifrequency HTECH Z12 GPS. In fact, the MS2 Bartington instrument enables us to use both sensors: MS2D for calibration and the MS2F which is adapted for data acquisition along opened grooves (Figure 10(a)). The distance between measured points is equivalent to the width of the sensor, that is, $\sim 1 \mathrm{~cm}$ in the case of MS2F.

Series of bulk magnetic susceptibility (MS) curves were drawn for each profile to determine MS variation versus depth. If we suppose that the precipitation of travertine takes place in horizontal or subhorizontal topographic conditions, lateral correlation between profiles can reveal postdeposit deformation. As example, to highlight lateral MS variation on successive profiles, even if they are taken at different altitudes, we compare three of them (Figure 10(b)). Preliminary results show that MS values are the strongest at the lower part of some profiles indicating the basement of the travertine series while other profiles show slightly elevated MS values at the 


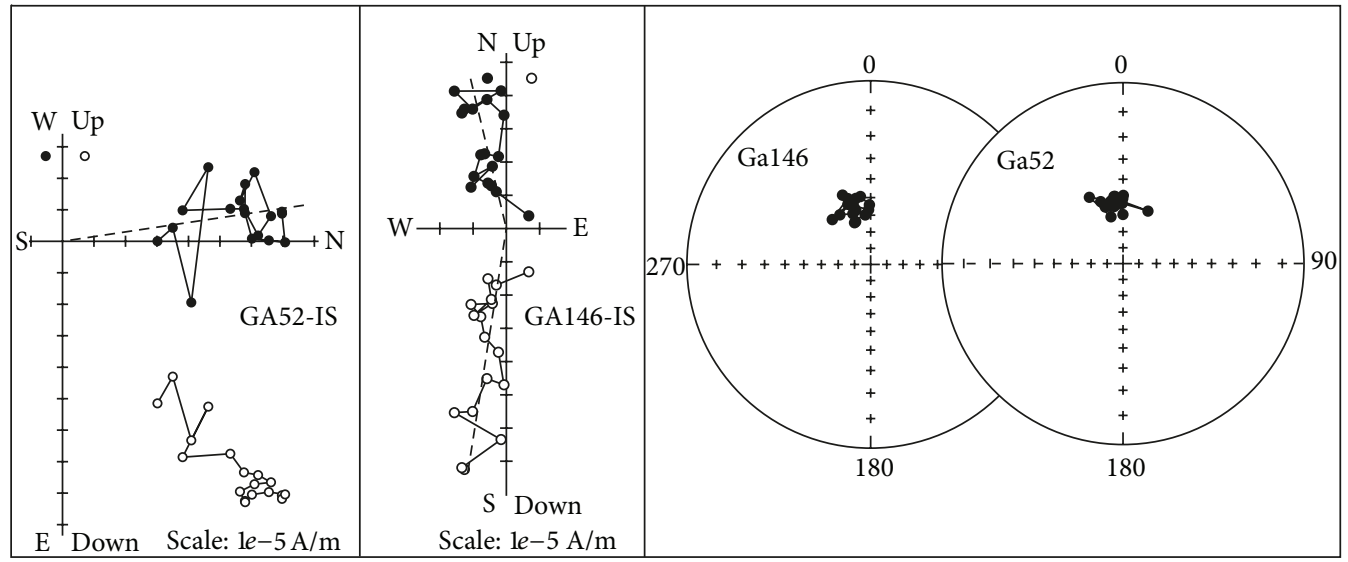

(a)

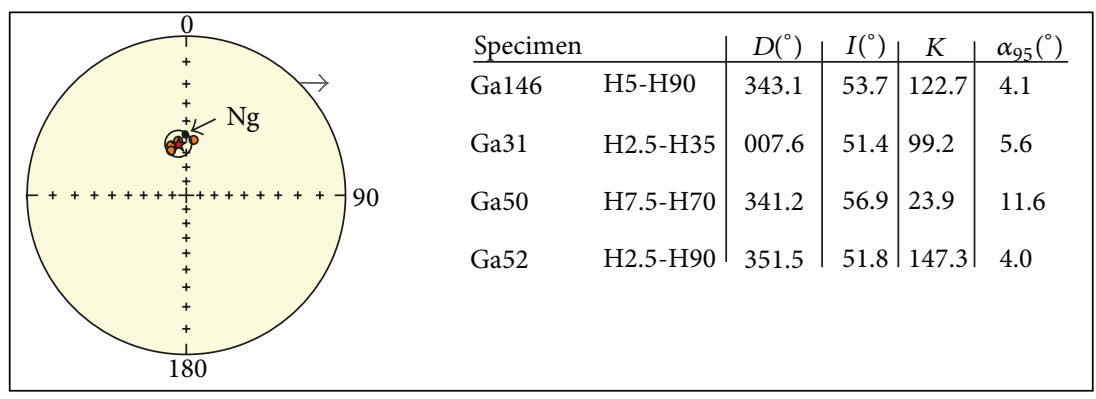

ฟ Mean magnetization direction $D=351.2, I=53.9, K=113.9, \alpha_{95}=8.6$

(b)

FIGURE 11: (a) Orthogonal projection diagram and equal area plot of the magnetization of two specimens of the pilot series; (b) preliminary paleomagnetic analysis on pilot travertine specimens: case of four specimens (Ga31, Ga50, Ga52, and Ga146) and the different paleomagnetic parameters including mean magnetization direction.

top, suggesting anthropogenic factors such as atmospheric deposition of magnetic spherules formed as combustion products (see HD 2 in Figure 10(b)). All sections show more lateral variation indicating some differences in the sedimentary processes within the travertine. In the case of profiles 1 , 2 , and 3 (Figure 10(b)) performed on travertine wall, it yields the probable paleocurrent flow. In that case, it evidences flow direction from south to north. Hence, the travertine deposits are growing northward (Figure 10(b)). Another hypothesis is that the MS profiles' variations can be mainly related to chemical origins, as the magnetic enrichment increases this magnetic parameter. Indeed, outside the anthropogenic enrichment origin observed on the top of profiles (example in HD 2), the little increase of the MS is probably due to the spas activity which mostly grows with tectonic activity (active faulting). Most indications are given by our preliminary paleomagnetic study carried out on the sampled travertine. A pilot series of eight standard paleomagnetic specimens was demagnetized under an alternating field (AF) at the cryogenic 2G magnetometer at CEREGE (France). The results show that most specimens exhibit more or less a good AF demagnetization where the total natural remnant magnetization (NRM) is deleted at around $2 \mathrm{mT}$ or at maximum of $4 \mathrm{mT}$, with weak NRM around $1.5 \times 10^{-6} \mathrm{Am}^{2}$, which attest of specific magnetite bearing mineralogy. In Figure 11(a), the orthogonal diagrams highlight that the NRM exhibits only one component despite the weakness of the NRM intensities. Only few specimens (e.g., Ga50 and Ga52) show hard AF demagnetization due to the presence of magnetite spherules. On the other hand, the demagnetization of the pilot series of specimens gives a good indication about the magnetic direction which suggests a Plio-Quaternary age (Figure 11(b)) [29]. Finally, this preliminary paleomagnetic approach, combining the travertine magnetic susceptibility and preliminary paleomagnetic analysis, can be used to demonstrate the spas activity. As suggested previously, using the MS profile signals, one can determine different levels of deposits related to high and/or low spas activity phases which can be attributed to instantaneous tectonic movement.

\section{Discussion}

4.1. Geological and Morphological Contribution. The travertine deposit of HD has been accumulated along an active normal fault which generated earthquakes in the past. The existence of extensional fractures out of the area attests that 
this structure somehow contributes to the pull-apart system of the Guelma basin. It is clear that travertine becomes deposited upon the inner and the outer walls as well and progressive widening of the fracture takes place. This is due to the continuation of the crustal tension, or high hydrostatic pressure within the ridge. The local buildups will result in a series of small interconnected mounds gradually increasing in height. This morphology attests that the water flowing from the fracture is often discontinuous, leading to a linear array of individual springs. Smaller movements occurred along the major fault or downslope movements and follow the fracture during earthquake activity (Figure 10). Good examples of tensional fractures are known at $\mathrm{HD}$, and the travertine landslide near the village was probably initiated by this process. Therefore, the HD fault could be responsible for the local seismic activity. This is corroborated by the focal mechanisms of several earthquakes which occurred along the western limit of the Guelma basin that exhibit an NNW-SSE fault plane.

The presence of hydrothermal sources at a given site can change the organization of drainage, so as they profoundly influence the fluvial systems and their development. In $\mathrm{HD}$, the principal drainage pattern is represented by Bou Hamdane River which crosses this zone in its northern side (Figure 2). As shown in Section 2, the overall morphology of the site of HD shows that the river was deviated from its primary flow position. This is evidenced, at the base of the front of travertine, by the presence of detrital material abandoned by the river as a terrace. The cemented alluvium modifies the Bou Hamdane River flow. This scenario is shown by the river bend that bypasses the northern boundary of the travertine area and the northern direction on the travertine flow deposit as suggested by the MS profiles. Hence, this river has been deviated $\sim 100 \mathrm{~m}$ to the north by the impinging travertine deposits during their development. After the initial incision of a primary flow of hydrothermal water from a shallow volcanic source (as shown by the gravity data), the evolution of the travertine deposits could be interpreted as an active hydrothermal feature related to active tectonics.

4.2. Geophysical Data. The gravity data show that the HD hydrothermal source is shallow and located at the south of the village. These data provide a picture of the hydrothermal deposits formation at depth surrounding the position of the heat source $(7 \mathrm{~km})$ to the surface. The chemical and physical parameters can explain the volcanic or plutonic nature of the origin source. The major gravimetric axe is superimposed to the position of HD and the numerous normal faults observed in the vicinity of HD. The preliminary paleomagnetic analysis corroborates a recent age of the travertine deposits and suggests that the surface deformation is of Quaternary age such as the surface rupture observed in the Roman career. The MS profiles highlight the $\mathrm{S}$ to $\mathrm{N}$ flow direction and attest of the probable increase in water mineralogical drift. The simple typical scenario proposed all over the world of such deposits (heated seat deep, subvertical fault, and hydrothermal steam) can be applied to the site of HD and surroundings.
4.3. Structural Implication. Previous geological studies in the Guelma basin did not reveal the existence of the tectonic lineament of HD-Roknia. This is due in part to the absence of structural investigation. This work has revealed minors fault structures in the NNW-SSE direction, with apparent normal movement outcropping in Miocene, Pliocene sandstones, and travertine. These young NNW-SSE fracture systems are juxtaposed to HD and Roknia spas. The recent activity of this fault is attested by the moderate earthquakes that occurred in this zone. The HD major fault is similar to the Bouchegouf, Hammam N'Bailis (Guelma region), and Sigus (to the west in Constantine region) active faults which are also juxtaposed to hydrothermal sources.

\section{Conclusion}

The different field observations and measurements evidenced an active tectonic structure with normal faulting along which a system of travertine was deposited. From tectonic point of view, the numerous fissures observed are parallel to the active extensional fault responsible for the local seismicity. As mentioned before, the HD case is similar to the travertine deposits at Pamukkale, Turkey [2], and at La Roche Fontaine, France [30] and also the fracturing of a Madang Province (New Guinea) travertine Pleistocene to Holocene deposit [3]. The $2003 \mathrm{HD}$ earthquake seems to be clearly related to the fault newly identified in this study (namely, HD Fault) which is seismogenic structure similar to the already known $\mathrm{H}$. N'Bailis, Bouchegouf, Sigus, and Ain Smara active faults.

\section{Acknowledgments}

This paper was supported by (Centre de Recherche en Astronomie, Astrophysique et Géophysique) CRAAG, Project code G002/08 (Contribution géophysique à l'étude de l'évolution géodynamique du bassin sédimentaire de Guelma (Algérie)). The authors are grateful to the Magnetic Laboratory of CEREGE (France) for the preliminary paleomagnetic pilot measurements. They thank Dr. A. Harbi for the numerous and fruitful discussions on the seismicity of the region. They are grateful to the Editor Dr. Gambino and anonymous reviewers for their comments, remarks, and suggestions.

\section{References}

[1] P. L. Hancock, R. M. L. Chalmers, E. Altunel, and Z. Çakir, "Travitonics: using travertines in active fault studies," Journal of Structural Geology, vol. 21, no. 8-9, pp. 903-916, 1999.

[2] E. Altunel and P. L. Hancock, "Morphology and structural setting of Quaternary travertines at Pamukkale, Turkey," Geological Journal, vol. 28, no. 3-4, pp. 335-346, 1993.

[3] W. F. Humphreys, S. M. Awramik, and M. H. P. Jebb, "Freshwater biogenic tufa dams in Madang Province, Papua New Guinea," Journal of the Royal Society of Western Australia, vol. 78, no. 2, pp. 43-54, 1995.

[4] A. Heimann and E. Sass, "Travertines in the Northern Hula Valley, Israel," Sedimentology, vol. 36, no. 1, pp. 95-108, 1989. 
[5] K. E. Bargar, "Geology and thermal history of Mammoth Hot Springs, Yellowstone National Park, Wyoming," United States Geological Survey Bulletin, vol. 1444, pp. 1-55, 1978.

[6] V. Lozek, "Molluscan characteristics of the Pleistocene warm periods with particular reference to the last interglacial," Berichte der Deutschen Gesellschaft fur Geologische Wissenschaft Reihe A, vol. 14, pp. 439-469, 1969.

[7] P. Ambert and A. Tavoso, "Les formations quaternaires de la vallée du Tarn entre Millau et Saint-Rome de Tarn," Paleobiologie-Continentale, vol. 12, pp. 185-193, 1981.

[8] A. Pentecost, H. A. Viles, A. S. Goudie, and D. H. Keen, "The travertine deposit at Shelsley Walsh, Hereford \& Worcestershire," Transactions of the Woolhope Naturalists Field Club, vol. 50, pp. 25-36, 2000.

[9] M. Julian and J. Martin, "Signification géomorphologique des tufs et des travertins," Bulletin de l'Association Géographique de France, no. 479-480, pp. 219-233, 1981.

[10] J. M. Vila, La chaine alpine d'Algérie orientale et des confins algéro-tunisiens [Thèse de Doctorat], Université de Pierre et Marie Curie, Paris, France, 1980.

[11] A. Harbi, S. Maouche, and A. Ayadi, "Neotectonics and associate seismicity in the Eastern Tellian Atlas of Algeria," Journal of Seismology, vol. 3, no. 1, pp. 95-104, 1999.

[12] P. Deleau, "Etude géologique des régions de Jemmaps, Hammam Maskoutine et du col des oliviers. Thèse," Bulletin: Service de la Carte Géologique de l'Algérie, vol. 2, no. 8, p. 583, 1938.

[13] H. Dib, "Guide pratique des sources thermales de l'Est Algérien," Mémoires du Service Géologique National, no. 15, p. 106, 2008.

[14] M. Meghraoui, Géologie des zones sismiques du Nord de l'Algérie. Paléosismologie, Tectonique Active et Synthèse sismotectonique [Thèse de Doctorat d'Etat], Université de Paris-Sud Orsay, 1988.

[15] D. Benouar, "Materials for the investigation of the seismicity of Algeria and adjacent regions during the twentieth century," Annali di Geofisica, vol. 37, no. 4, p. 862, 1994.

[16] A. Harbi, A. Peresan, and G. F. Panza, "Seismicity of Eastern Algeria: a revised and extended earthquake catalogue," Natural Hazards, vol. 54, no. 3, pp. 725-747, 2010.

[17] M. Meghraoui, J. L. Morel, J. Andrieux, and M. Dahmani, "Néotectonique de la chaîne Tello-Rifaine et de la Mer d'Alboran: une zone complexe de convergence continentcontinent," Bulletin de la Société Géologique de France, vol. 167, pp. 143-159, 1996.

[18] A. Harbi, S. Maouche, and H. Benhallou, "Re-appraisal of seismicity and seismotectonics in the north-eastern Algeria part II: 20th century seismicity and seismotectonics analysis," Journal of Seismology, vol. 7, no. 2, pp. 221-234, 2003.

[19] S. Maouche, M. Meghraoui, C. Morhange, S. Belabbes, Y. Bouhadad, and H. Haddoum, "Active coastal thrusting and folding, and uplift rate of the Sahel Anticline and Zemmouri earthquake area (Tell Atlas, Algeria)," Tectonophysics, vol. 509, no. 1-2, pp. 69-80, 2011.

[20] G. Glacon and H. Rouvier, "Lunité du col d'Adissa (confins Algéro-tunisiens septentrionaux): lithologie et stratigraphie; conséquences structurale et paléogéographique de son individualisation," Bulletin de la Société Géologique de France, vol. 7-13, pp. 100-110, 1972.

[21] G. A. Waring, "Thermal springs of the United States and other countries of the world, a summary," United States Geological Survey, vol. 492, pp. 1-383, 1965.
[22] A. Deschamps, M. Bezzeghoud, and A. Bounif, "Seismological study of the Constantine (Algeria) earthquake (27 October 1985)," in Seismicity, Seismotectonics and Seismic Risk of the Ibero-Maghrebian Region, J. Mezcua and A. Udias, Eds., vol. 8, pp. 163-173, Instituto Geográfico Nacional, Madrid, Spain, 1991.

[23] S. Guigue, Les sources thermominérales de l'Algérie. Tome I et II, Serv. Carte Géol. de l’Algérie, 3ème série, 5ème et 9ème fasc, 1940.

[24] D. McKenzie, "Active tectonics of the Mediterranean region," Geophysical Journal. Royal Astronomical Society, vol. 30, pp. 109-185, 1972.

[25] J. M. Nocquet and E. Calais, "Geodetic measurements of crustal deformation in the Western Mediterranean and Europe," Pure and Applied Geophysics, vol. 161, no. 3, pp. 661-681, 2004.

[26] E. Serpelloni, G. Vannucci, S. Pondrelli et al., "Kinematics of the Western Africa-Eurasia plate boundary from focal mechanisms and GPS data," Geophysical Journal International, vol. 169, no. 3, pp. 1180-1200, 2007.

[27] A. Harbi and S. Maouche, "Les principaux séismes du Nord-Est de l'Algérie," Mémoires du Service Géologique National, no. 16, p. 106, 2009.

[28] A. Abtout, L. Hamai, and B. Bouyahiaoui, Etude gravimétrique de la région de Guelat Bousbaa-Nador et du bassin d'Oued Zenati.(Guelma): reconnaissance des aquifères. Rapport ANRH (Agence National des Ressources Hydriques), 2005.

[29] J. D. A. Zijderveld, "AC demagnetization of rocks: analysis of results," in Method in Paleomagnetism, D. W. Collinson, K. M. Creer, and S. K. Runcorn, Eds., pp. 254-286, Elsevier, Amsterdam, The Netherlands, 1967.

[30] C. Pareyn and H. Salimeh, "Dislocation catastrophique d'un tuf lapidifie dans l'arriere-pays d'Honfleur (Calvados, France)," Bulletin Centre de Géomorphologie du Caen, vol. 38, pp. 151-159, 1990. 

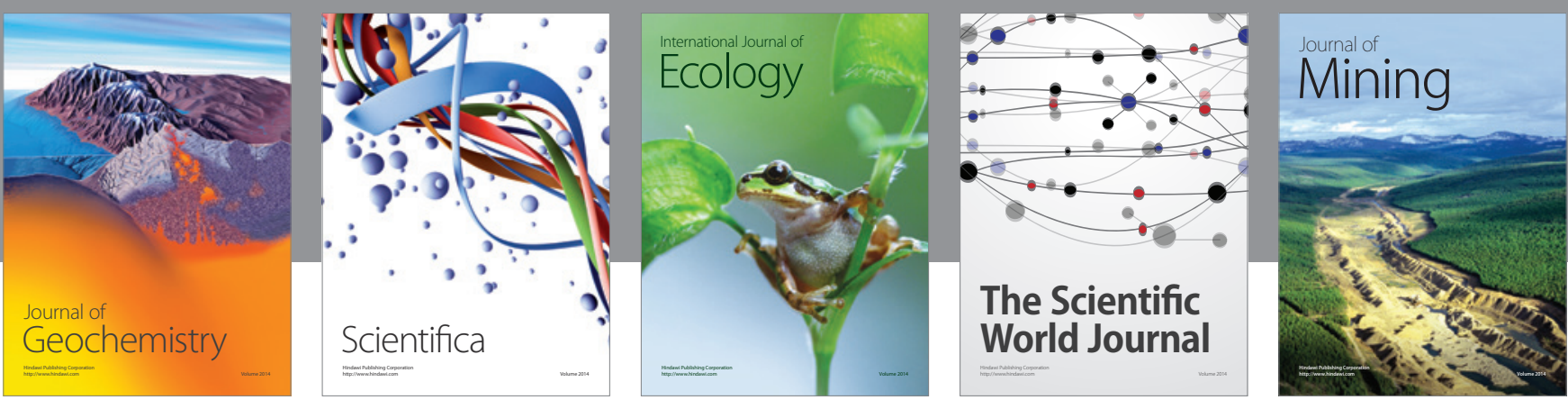

The Scientific World Journal
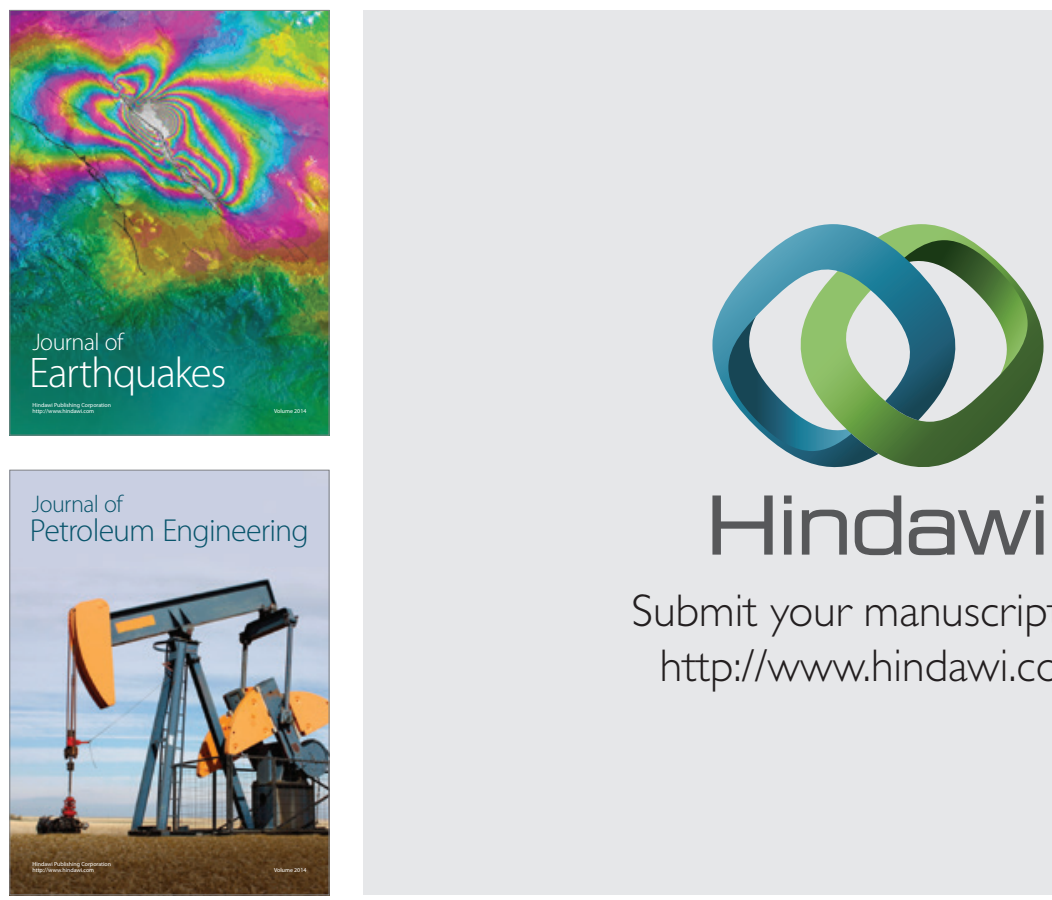

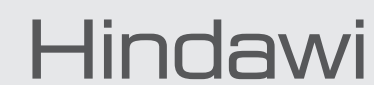

Submit your manuscripts at

http://www.hindawi.com
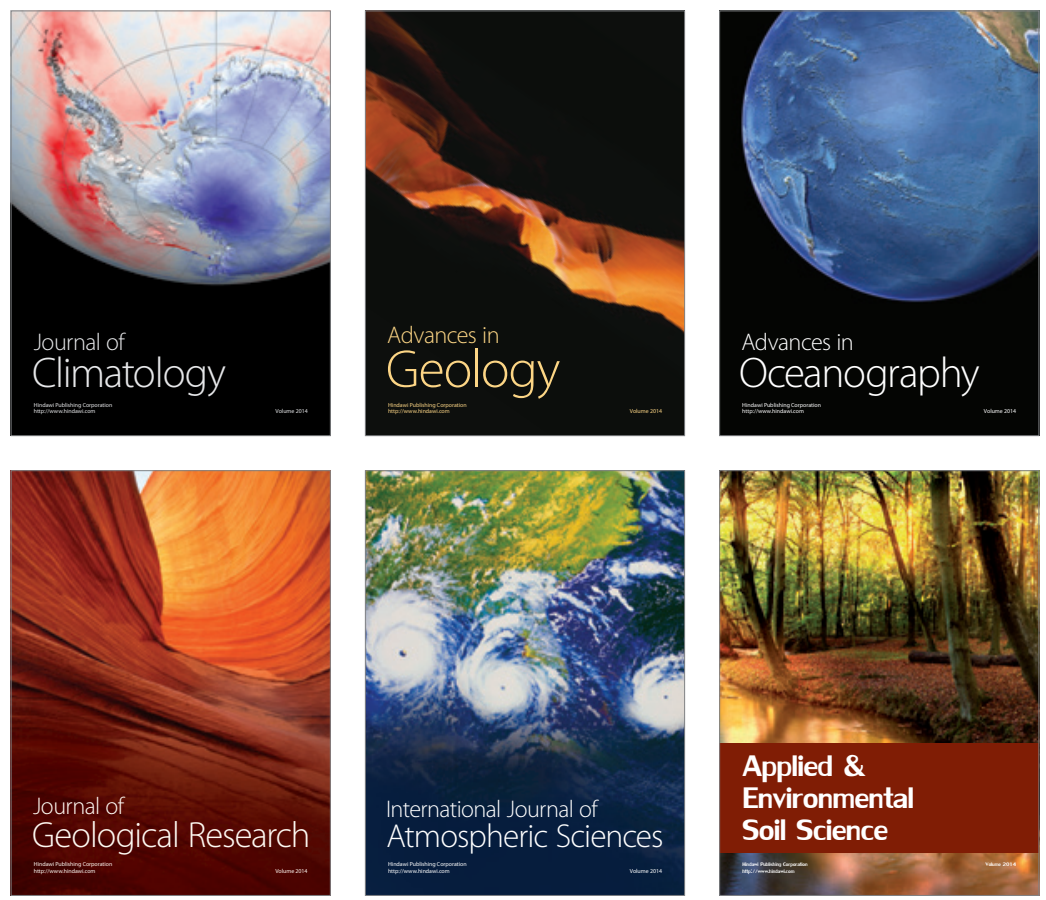
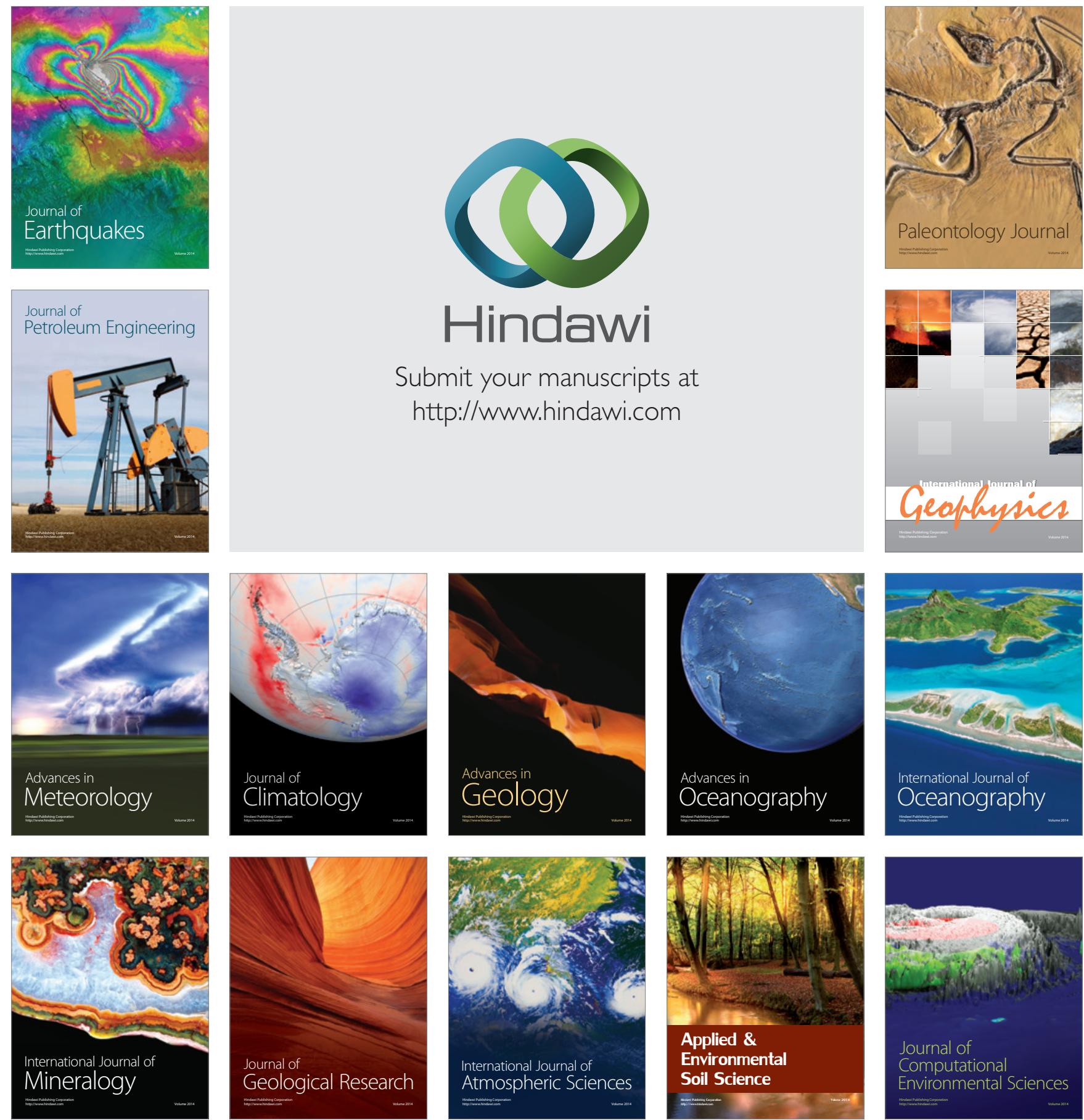